\title{
In Search of a Just Leader in Islamic Perspective: An Analysis of Traditional Malay Literature from the Perspective of $A d a b$
}

\author{
Muhd Norizam Jamian ${ }^{1} \&$ Shaiful Bahri Md Radzi ${ }^{1}$ \\ ${ }^{1}$ School of Malay Language, Literature and Culture, Faculty of Social Sciences and Humanities, Universiti \\ Kebangsaan Malaysia, Bangi, Selangor, Malaysia \\ Correspondence: Muhd Norizam Jamian, School of Malay Language, Literature and Culture, Faculty of Social \\ Sciences and Humanities, Universiti Kebangsaan Malaysia, 43600 UKM Bangi, Selangor, Malaysia. E-mail: \\ norizam@ukm.my
}

Received: March 14, 2013 Accepted: April 1, 2013 Online Published: April 28, 2013

doi:10.5539/ass.v9n6p22

URL: http://dx.doi.org/10.5539/ass.v9n6p22

\begin{abstract}
This paper discusses the functions of traditional Malay literature as a platform for the formation of human civilisation to create a just leader in fulfilling his responsibility as a caliph of Allah on earth. Justice in Islam means to put something in the exact, right and proper position in all aspects of human life. Justice becomes one of the important pillars in human life, especially for a leader. The data of this study involves the edited texts of traditional Malay literature, consisting of a variety of genres produced or copied from the 15th to 19th century, namely Hikayat Maharaja Ali, Hikayat Raja Pasai, Taj al-Salatin, Bustan al-Salatin, Thamarat al-Muhimmah, Hikayat Abu Syahmah, Hikayat Raja Jumjumah and Hikayat Ibrahim ibn Adham. This study explores and analyzes the texts of traditional Malay literature by using an adab approach based on the Syed Muhammad Naquib Al-Attas (2001) frame work. As an adab literature, this study demonstrates that the works of traditional Malay literature could assume as a major role in forming the just leader. Traditional Malay literary works serve as planters of noble manners to create a balanced human both mentally and physically. Elements of justice presented through the traditional Malay literary works have become guidelines for audience in seeking for a guided relationship both with their Creator (hablumminaLLah) and fellow human beings (hablumminannas) as well as explicating the divine purpose of every living human being in this world - to become His vicegerent and servant. Every leader has to implement this dual role with just and balanced. As His servants, the leader needs to obey all His commandments and use their wisdom to guide their lives. As His vicegerent, the just leader needs to perform their duties and responsibilities with trust, and fairness in resolving the problems and sentencing.
\end{abstract}

Keywords: justice, leader, vicegerent of God, traditional Malay literature, adab

\section{Introduction}

The concept of justice in Islam is holistic and inclusive. Justice is not limited on the question of government, judicial and religious law alone but the whole point of representing human life without exception. Islamic view of justice is not only a prorated because the division will lead the oppressed is not getting right or gets something that is not right. Hence the meaning of true justice is putting things in a true and fair (Wan Mohd. Nor, 2005: 45). In other words, justice involves the granting of rights to the party entitled. Justice in Islam is also not the same as neutrality or impartiality because justice is in favour of the truth (Wan Mohd. Nor, 2005: 75).

This paper discusses the concept of justice leaders featured in the traditional Malay literary works from the perspective of $a d a b$. This paper also discusses the functions of traditional Malay literature as a platform for the formation of human civilisation to create a just leader in fulfilling his responsibility as a caliph of God on earth. The data of this study involves the edited texts of traditional Malay literature, consisting of a variety of genres produced or copied from the 15th to 19th century, namely Hikayat Maharaja Ali, Hikayat Raja Pasai, Taj al-Salatin, Bustan al-Salatin, Thamarat al-Muhimmah, Hikayat Abu Syahmah, Hikayat Raja Jumjumah and Hikayat Ibrahim ibn Adham. This study explores and analyzes the texts of traditional Malay literature by using an $a d a b$ approach. As an $a d a b$ literature, this study demonstrates that the works of traditional Malay literature could assume as a major role in forming the just leader. 


\section{The Concept of $\boldsymbol{A d a b}$}

Literature in Islam is known as al-adabi which means literature that comes from the fine soul (refined) and aims to educate and nurture the public conscience with the values until their souls were to be refined and tender (Shafie, 1996: 118-151). Adab was the Arabic word used for literature which is derived from a meaning of etiquette, and implies politeness, culture and enrichment. Adab also can be described as "disciplines of the mind", "good qualities and attributes of the mind and soul" and "good breeding".

The original sense of the word was simply "norm of conduct", or "custom", derived in ancient Arabia from ancestors revered as models. As such practice was deemed praiseworthy in the medieval Muslim world, adab acquired a further connotation of good breeding, courtesy, and urbanity. Parallel to and growing out of this expanded social meaning of $a d a b$ there appeared an intellectual aspect. Adab became the knowledge of poetry, oratory, ancient Arab tribal history, rhetoric, grammar, philology, and non-Arab civilizations that qualified a man to be called well-bred, or $a d \bar{i} b$. Such men produced a vast and erudite $a d a b$ literature, concerned with man and his achievements and written in a style rich in vocabulary and idiom, and usually expressive and flexible.

$A d a b$ is one of the most important master ideas which Syed Muhammad Naquib al-Attas has offered to modern Muslim thought; a key traditional Islamic concept which he has rediscovered and systematically explained and linked to other Islamic key terms and concepts in ontology, epistemology and education, ethics, aesthetics and literatures. Based on what he regards as the original Islamized meaning of adab and on an analysis of its semantic field, al-Attas proposes his own definition (Syed Muhammad Naquib al-Attas, 2001: 118):

$A d a b$ is recognition and acknowledgement of the reality that knowledge and being are ordered hierarchically according to their various grades and degrees of rank, and of one's proper place in relation to that reality and to one's physical, intellectual, and spiritual capacities and potentials.

\section{The Concept of Justice in Islam}

In the Islamic worldview, justice denotes placing things in their rightful place. Justice means to put something in the exact, right and proper position in all aspects of human life. It is also a moral virtue and an attribute of human personality. It creates a state of equilibrium in the distribution of rights and duties. Justice, as defined in the Quran, commands mankind to behave in a fair and just manner; to protect the rights of others; to be fair and just with people; to side with the one who is under oppression; to help and be fair with the needy and orphans; and to be just and not go beyond the boundaries set by God, even with the enemies.

Islam has placed justice as a milestone in the life of his people. Islam also provides specific and clear definition of justice which means to put something in the exact, right and proper position in all aspects of human practice. Unlike the West, which outlines that justice should involve two parties, for example, between society and the nation or the people and the king, Islam have set that justice should start and end in all human beings themselves (Wan Mohd. Nor, 2005: 45; Syed Muhammad Al-Naquib Attas, 2001: 37).

From another perspective, there are two bands which form the basis or principle of justice in Islam. First, the justice in Islam involves putting something in the right position, right and proper in every corner of human life. Second, just treatment would lead to a balance or equilibrium situations in human life, not only in the mortal life but also the eternal life.

Traditional Malay literary works serve as planters of noble manners to create a perfectly balanced individual both mentally and physically in their lives. Elements of justice presented through the traditional Malay literary works have become guidelines for audience in seeking for a guided relationship both with their Creator (hablumminaLLah) and fellow human beings (hablumminannas) as well as explicating the divine purpose of every living human being in this world - to become His vicegerent and servant. Every leader has to implement this dual role with just and balanced. As His servants, the leader needs to obey all His commandments and use their wisdom to guide their lives. As His vicegerent, the just leader needs to perform their duties and responsibilities with trust, and fairness in resolving the problems and sentencing.

\section{The Qualities of the Just Leader in the Traditional Malay Literature}

The qualities and rules required of leaders in order to practice justice can be summarized as follows:

\subsection{Carry out Duties and Responsibilities with Trust and Integrity}

Position as a leader does not mean simply being the head of government, but instead assume a greater trust from Allah SWT as a leader to all walks of life throughout the country. Leadership role will be evaluated by God in the afterlife and a reward granted or sin committed based on the practice. This has been pointed out in Bustan al-Salatin (Jelani, 2003: 52): 
Hai yang amat elok, makanya tuan hambalah yang lagi akan ditanyai Allah Taala pada hari kiamat daripada segala makhluk-Nya. Maka jika kuasa tuan memeliharakan diri tuan hamba daripada neraka, maka tuan hamba peliharakanlah diri tuan hamba.

[Therefore you will be questioned on the Day of Resurrection by Allah Almighty from all His creatures. So use your power to keep yourself from hell.]

Leaders must be humble and know their proper duties towards God and the people. Just leaders must know their proper duties towards God and their people. A humble leader will remember his duties at all times and avoid being arrogant and oppressive towards his people. A just leader is always engage with the people he led. Leaders also have to know the problems and needs required by the people directly without going through intermediaries. In fact, just leader will always maintain the safety and well-being of its people.

A good example is the story of generous Caliph Umar al-Khattab helping a hungry old woman with her children in Medina to have some food at night. This story presented in Bustan al-Salatin (Jelani, 2008: 24):

Pada suatu malam, Khalifah Umar al-Khattab dan Zaid ibn Muslim (Zayd ibn Aslam) berjalan-jalan di sekitar kota Madinah. Dalam perjalanan tersebut mereka telah berjumpa dengan seorang wanita dan tiga orang anaknya yang sedang kelaparan. Khalifah Umar al-Khattab segera bertanya tentang masalah wanita tersebut dan tentang apa yang sedang dimasaknya. Wanita tersebut menjawab: "Suatu pun tiada di dalam periuk ini, hanya hamba melalikan kanak-kanak ini supaya sangka segala kanak-kanak ini ada hamba menanak makanan, nescaya sabarlah ia."

Setelah mendengar cerita wanita berkenaan, Khalifah Umar al-Khattab segera kembali ke kota Madinah dan membeli beberapa barang makanan. Zaid ibn Muslim cuba membantu Khalifah Umar al-Khattab untuk membawa barang makanan tersebut tetapi dihalang oleh Khalifah dengan kata-kata: "Hai Zaid ibn Muslim, jikalau engkau menanggung tanggunganku ini maka siapa jua menanggung dosaku pada hari kiamat dan siapa menahan seksa-Nya akan daku?"

Apabila tiba semula di tempat wanita tadi, Khalifah Umar al-Khattab segera memasak barang makanan yang dibawanya dan mempersilakan wanita dan anak-anaknya makan. Wanita tersebut mengucap syukur kepada Tuhan terhadap rezeki yang diperolehnya. Setelah selesai mereka makan, Khalifah Umar al-Khattab berkata kepada wanita tersebut: "Hai perempuan, jangan engkau serapa akan Umar, bahawasanya ia tiada mengetahui khabarmu dan segala khabar anakmu."

[One night Caliph Umar al-Khattab was walking around Medina with Zaid ibn Aslam, and found a hungry woman with three children sheltering outside the city. The woman had placed a pot on a fire, but the pot only contained water. The woman did this just to make her children patient. The Caliph then went back to the city and brought a sack of flour which he slung over his shoulder. Zaid ibn Aslam wanted to help the Caliph but the Caliph replied: "If you carry this load, who will carry my load of sin before God?" When they reached the place again, Caliph Umar himself then cooked some food for the family. The old woman blessed the Caliph. The Caliph then asked for forgiveness from the old woman because he no knowledge of her problems.]

\subsection{Leaders Must Give Advice to Their Ministers and Other Court Officials}

One of the important duties of leaders is to give advice to their ministers or servants. It is a leader's responsibility to choose his ministers or servants and he also has a responsibility to ensure that these court officials are doing their jobs properly and never to tolerate their unjust conduct. Among other things, the advice that leaders should give to their ministers concerns their duties to God and their people, the use of power, being just, and being fond of knowledge. A good example can be read in the story of Nusyirwan Adil who went hunting and asked his men to buy salt at the local price. This story appeared in Bustan al-Salatin.

One day Nusyirwan Adil went hunting with his men and asked them to prepare food. But they did not have salt. Nusyirwan Adil asked his men to buy salt from the local people, and said: "You must buy this salt at the local price, don't pay less, so you will not harm the custom." One of his men asked, "O lord, can a low price for salt harm the custom?" Nusyirwan Adil then replied, "Don't you know, there was only a little injustice in this world in the past, but time after time, every king has added to the injustice." (Jelani, 2008: 147-148).

This story give lessons to the audience that a leader should always monitor the behavior of each officer who served under his command, so they always keep the welfare of the people. The leaders also must show a good example to his subordinates that they should practice the noble moral values against the people. 


\subsection{Leaders Must Use Their Power Properly}

Every leader has power which he must use properly, particularly in dealing with his people. For instance, they must give fair judgement based on the law. Every accusation against a person must be examined thoroughly even if the accusations were to come from the Prime Minister or have been made by a relative. This is to avoid misjudgement of people and at the same time to avoid misuse of power among ministers. Leaders are also warned not to kill people without any proper reason based on the law.

In addition, a just leader must have the nature of love against those he leads. The nature of love will makes a leader always thinking about the well-being of its people. The nature of love will also encourage the leaders to always be patient, generous, polite, humble, trustworthy, hardworking, honest, forgiving and friendly with people. Consequently, people will also love and prays for the healthy of the leaders.

Otherwise unjust leaders directly violated the principles of justice in his reign. Such attitude of the leaders will not bring benefits to the people and country but invite disaster and ruin themselves and their country. Failure to be just leader just not only makes the people to be hateful, but also will destroy the country and the government. This was shown through the Hikayat Maharaja Ali (Mohd Yusof, 1989: 84-85):

Setelah perdana menteri itu mendengar sembah segala isi negeri itu demikian, maka katanya, "Jika demikian, marilah kita muafakat, kecil besar, tua dan muda, kita sekalian nyahkan raja kita ini dari dalam negeri ini, kerana tiada adilnya menghukumkan kita." Telah sudah ia mesyuarat sekalian, maka semuanya pun masuk menghadap Maharaja Ali itu. Maka sembah perdana menteri dan sekalian mereka itu, "Ya syah alam, bahawasanya nyahlah tuanku dari dalam negeri ini, kerana patik ini sekalian tiada suka bertuankan raja yang tiada adil! Kerana tuanku sayangkan anak seorang, rosak isi negeri ini habis binasa! Dan jikalau tuanku tiada mahu keluar, biarlah patik sekalian keluar akan pergi mencari di mana raja yang adil; di sanalah patik perhambakan diri."

[After the prime minister heard the complaints from the people, he said, "If so, let us make a consensus to drive off our king from the state, because he judge unfairly." After the meeting, they met Maharaja Ali. The prime minister said, "O my lord, you need to go away from this country because we do not want to have an unjust king. Because of your love to your son, this country has been exhausted and perished! And if you do not want to go out, let us all to go out to find where the just king is."]

Through the tale, the Maharaja Ali displayed failure in fulfilling its responsibilities with fairness, not only the head of government but also as head of the family. As a leader, Maharaja Ali failed to punish and judge his eldest son, Raja Baharum Shah who have a bad behaviour and have committed various offences such as assault, murder and 'picked up the wife of another' (Mohd Yusof, 1989: 84). As a father, Maharaja Ali was unable to form Raja Baharum Shah to be in good character with generous and courteous disposition. The failure of Maharaja Ali to lead with fairness has caused anger and discontent among the people, causing mounting Maharaja Ali and the whole family driven out by the people themselves.

Meanwhile, the Hikayat Raja Pasai also stressed that the tyranny of a ruler is a starting point of the fall of the government. Pasai suffer such destruction as its king, Sultan Ahmad Perumudal Perumal unjust not only against citizens but also to his own sons and daughter (Jones, 1999: 60):

... maka segala orang dalam jong itu pun bertanya, katanya, "Apa nama negeri ini?" Maka sahut orang mengail itu, "Adapun nama negeri ini Pasai." Maka kata orang dalam jong itu, "Apa ada khabar dalam negeri ini?" Maka sahut orang mengail itu, "Adapun khabar dalam negeri ini badak makan anaknya." Maka kata orang dalam jong itu, "Tiada kami tahu apa ertinya katamu itu." Maka sahutnya, "Adapun ertinya, paduka sultan yang dalam negeri Pasai ini membunuh anaknya dua orang, seorang bernama Tun Beraim Bapa, dari karna sultan itu berahi akan anaknya perempuan seorang bernama Tun Medam Peria dan seorang bernama Tun Takiah Dara, dan anaknya Tun Abdul Jalil pun dibunuhnya dibuangkannya dalam laut Jambu Air ini, sebab ia menengar khabar Tuan Puteri Gemerenceng datang dari benua Jawa terlalu amat ia berahi akan Tun Abdul Jalil itu, mayat Tun Abdul Jalil itu pun disuruhnya buangkan dalam laut Jambu Air ini; itulah erti kata kami badak makan anaknya."

[... then all the people in the junk asked, "What is the name of this country?" The fisherman said, "The name of this country is Pasai." Then the people in the junk asked, "What happened in this country?" The fisherman said, "In this country there is a rhino eat their young." Then the people in the junk said, "We do not understand." And he said, "I means, the Pasai king killed his two sons, one named Tun Beraim Bapa, as the king fell in love with his daughter who is named Tun Medam Peria and Tun Takiah 
Dara; and his second son, Tun Abdul Jalil was killed in the Jambu Air sea because he heard that the Tuan Puteri Gemerenceng from Java fell in love with Tun Abdul Jalil; Tun Abdul Jalil's body was thrown into the Jambu Air sea; that is the meaning of rhino eat their young."]

The cruelty of Pasai king, Sultan Ahmad Perumudal Perumal is revealed when he is about to kill son, Tun Beraim Bapa who tried to stop the king's desire to "snakehead eat children" with his daughters, Tun Medam Peria and Tun Takiah Dara. As a result of his jealousy towards his son, the handsome Tun Abdul Jalil that was favoured by the Javanese princess, Tuan Puteri Gemerenceng, Sultan Ahmad willing to kill him and throw his body into the Jambu Air sea. Although Sultan Ahmad felt regret (Jones, 1999: 61) later, but it was too late for the government when finally Pasai has been attacked and conquered by Majapahit kingdom from Java.

This passage emphasizes that a leader must protect the rights of people with justice and wisdom. Abuse and violence for the people will lead to the disintegration and destruction of a government. This reminder is specifically directed not only to the king, but also all the people because every human being created by God Almighty as the inheritors of the earth.

\subsection{Justice in Resolving the Problems and Sentencing}

Besides being wise and fair in judgement, leaders also must take the responsibility for what they have done and be ready to correct their wrongdoings. Wherever possible, they must forgive their people, especially when it is a mistake made by them. A good example can be read in the story of Ma'mun al-Rashid who tried to punish an innocent man.

In the days of Caliph Ma'mun al-Rashid, a particular person had committed an offence and fled. Caliph Ma'mun al-Rashid ordered a brother of the man to be brought before him and asked that he should produce his brother, or else he would be put to death. The man then read a verse from the Quran: "One shall not bear the burden of another", which means that men shall not seize anyone for the offence of another. Caliph Ma'mun al-Rashid then realised his fault and released the innocent man (Jelani, 2008: 174).

In addition, a fair leader must also be sentenced with firm and fair. Punishment should be meted out justice, not bias or favouritism. In other words, leaders should be sentenced accordingly without distinction according to rank and lineage. The justice of Umar al-Khattab in executing the sentence as demonstrated through the Hikayat of Abu Syamah must be followed (Mohd Yusof, 1989: 26):

Maka masa itu amirulmukminin Umar beranak dua orang laki-laki. Maka dibunuhnya seorang anaknya kerana ia tiada mahu masuk agama Islam dan lagi seorang dibunuhnya juga dengan cemeti kerana ia berzina dan minum arak. Demikianlah hukumnya baginda Umar radiallahuanhu akan anaknya yang kedua itu adanya.

[Caliph Umar has two sons. He killed the first son because he doesn't want to convert to Islam; and he killed his other son with a whip because he committed adultery and drinking alcohol. That is the punishment of Umar against both of his son.]

As a fair leader, the Caliph Umar al-Khattab, although penalties are willing against own son. Despite having the power to grant amnesty or commute punishment, Umar still bold enough to condemn to death the children who have violated laws of God. Caliph Umar's firmness in upholding justice has made him so respected and loved by the people.

\subsection{Obey All His Commandments as His Servant}

Justice in Islam begins and ends in all human beings themselves. A fair man in his own will be able to know themselves and their place in the presence of God alone. Man will feel himself realize that he owes, in its sole and absolute power to God (Syed Muhammad Naquib Al-Attas, 1977: 20). Conscious human will feel grateful to God Almighty who has created and bestowed many favours over the life of the world. In addition to acknowledge the greatness of God, human beings just on themselves to their position as the servant of a compulsory subject and obedient in fulfilling the commands of Allah and leave the ban.

The importance of obeying the command of Allah Almighty as the manifestation of His servants who feared, also displayed in the Hikayat Raja Jumjumah. Raja Jumjumah is a king who controlled the land of Sham. Despite diligent charity, Raja Jumjumah default on matters of religion and a lot of fun to spend time without performing the command of Allah SWT. When he died, the king put in the fire and receives a painful punishment from Allah SWT. He also witnessed the torture response to a variety of people who disobeys his commandments. After completing the punishment, the skull of Raja Jumjumah thrown into the desert before encountered by Nabi Isa, and turned back to the natural world with his miracles. Revived a second chance in the 
world has to give repentance to Raja Jumjumah and he has refused to dedicate this life fully to God. Raja Jumjumah also advise people to always obey the command of Allah Almighty (Mohd Yusof, 1989: 73):

Maka berkata Jumjumah, "Hai menteriku, dan rakyatku sekalian. Sekarang aku tidak mahu menjadi raja lagi dan aku tidak berkehendak kepada harta benda aku sekalian itu dan aku hendak memberi nasihat kepada kamu sekalian supaya kamu menurut perintah dan firman Tuhan yang sebenar. Janganlah kamu sekalian lalai dan asyik kepada lain akhirnya kamu sesal tiada berguna. Dunia ini tempat kita bertumpang buat sementara hidup dan cari bekalan kepada akhirat; itulah tempat kita kekal selama-lamanya." Maka sekalian menteri dan rakyat pun menurut bagaimana nasihat Jumjumah itu sekalian.

[So said Jumjumah, "O my minister and all my people. Now I do not want to be king anymore and I do not need all of my wealth, and I want to give advice to you to follow the order and word of God. Don't remiss with the worldly life pleasures. We live in this world only temporarily; therefore, we should use this world to get provisions in preparation for the afterlife: that is where we stay forever." And all the ministers and people follow the advice of Jumjumah.]

This tale admonishes the audience to realize their rights and responsibilities as His servants in the world. They need to realize they themselves will stunt the side of the Creator. They should not be preoccupied with the pleasures of the world to remember to perform all the command of Allah SWT. Only by becoming obedient servant, that performs each commandment and leaves all His ban will ensure the happiness in the world and the hereafter.

\subsection{Using the Intellect as a Guide}

The intellect is an instrument for human acquiring knowledge about the teachings and helps him carry out responsibilities and duties as religious. The intellect allows people to think rationally about the manners and procedures of human life as well as driving to the wisdom and justice. The intellect is the faculty which created wisdom. Thus justice had born emission wisdom, the human ability to put something into place that fit and meet the coordination capacity. String, came the balance and moderation in a variety of human actions in seeking the well-being in the world and the hereafter (Syed Muhammad Naquib Al-Attas, 2001: 83-88).

Intellectual interest in creating a person who has just also emphasized in Thamarah al-Muhimmah by Raja Ali Haji. With particular reference to their leader, Raja Ali Haji said that the mind and intellect are the key element that makes human knowledge and thus can carry out a fair punishment on his followers. Only with the knowledge to create impartiality in him (Hasan, 1996: 180):

"Segala raja-raja dan orang besar-besar jika tiada dengan ilmu dengan apa hendak menghukumkan segala manusia."

[For all kings and rulers, without the knowledge, how they want to judge their peoples]

\section{Conclusion}

A just leader will lead his people and country to happiness, harmony and prosperity. On the other hand, unjust leaders will ruin their people and country and become the cause of their unhappiness. Their bad deeds go against God's guidance and they will be punished whether on earth or after death. As an adab literature, this study demonstrates that the works of traditional Malay literature could assume as a major role in forming the just leader. These qualities of a just leader are presented through the traditional Malay literature as guidelines for the audience in order to form the just leader.

Elements of justice presented through the traditional Malay literary works have become guidelines for audience in seeking for a guided relationship both with their Creator (hablumminaLLah) and fellow human beings (hablumminannas) as well as explicating the divine purpose of every living human being in this world - to become His vicegerent and servant. Every leader has to implement this dual role with just and balanced. As His servants, the leader needs to obey all His commandments and use their wisdom to guide their lives. As His vicegerent, the just leader needs to perform their duties and responsibilities with trust, and fairness in resolving the problems and sentencing.

\section{References}

Al-Attas, S. M. N. (1977). Islam: Faham Agama dan Asas Akhlak. Kuala Lumpur: Angkatan Belia Islam Malaysia.

Al-Attas, S. M. N. (1990). Islam dalam Sejarah dan Kebudayaan Melayu. Petaling Jaya: Angkatan Belia Islam Malaysia. 
Al-Attas, S. M. N. (1995). Prolegomena to the Metaphysics of Islam. Kuala Lumpur: Institut Antarabangsa Pemikiran dan Tamadun Islam.

Al-Attas, S. M. N. (2001). Risalah untuk Kaum Muslimin. Kuala Lumpur: Institut Antarabangsa Pemikiran dan Tamadun Islam.

Al-Ghazali. (2000). Pedoman Orang Mukmin. Translated by Haji Osman Jantan. Singapura: Pustaka Nasional.

Ali, A. (Ed.). (1999). Kisah-kisah Nabi Yusof dalam Kesusasteraan Melayu. Kuala Lumpur: Dewan Bahasa dan Pustaka.

Braginsky, V. I. (1993). The System of Classical Malay Literature. Leiden: KITLV Press.

Braginsky, V. I. (1998). Yang Indah, Berfaedah dan Kamal: Sejarah Sastera Melayu dalam Abad 7-19. Jakarta: INIS.

Ensiklopedia Islam. (2004). Kuala Lumpur: Dewan Bahasa dan Pustaka.

Hamdan, H. (Ed.). (1990). Surat al-Anbiya'. Kuala Lumpur: Dewan Bahasa dan Pustaka.

Hari, Z. (1985). Insan Kamil: Citra Sufistik al-Jilli tentang Manusia. In M. D. Rahardjo (Ed.), Konsepsi Manusia Menurut Islam. Jakarta: Pustaka Grafitipers.

Harun, M. P., Ismail, H., Siti Hawa, S., Abu Hassan, S., Abdul Rahman, K., \& Jamilah, H. A. (2006). Kesusasteraan Melayu Tradisional (3rd ed.). Kuala Lumpur: Dewan Bahasa dan Pustaka.

Hasan, J. (1996). Raja Ali Haji dan Karya-karyanya. Riau: Pusat Pengajian Bahasa dan Kebudayaan Melayu, Universitas Riau.

Ismail, H. (1974). The Study of Traditional Malay Literature with a Selected Bibliography. Kuala Lumpur: Dewan Bahasa dan Pustaka.

Ismail, H. (1983). The Malay Islamic Hikayat (Monograph 1). Bangi: Penerbit Universiti Kebangsaan Malaysia.

Ismail, H., \& Wahyunah, A. G. (Eds.). (2002). Hikayat Para Nabi dan Tokoh-tokoh Islam dalam Kesusasteraan Melayu Tradisional. Kuala Lumpur: Dewan Bahasa dan Pustaka.

Jabatan Perdana Menteri. (1982). Tafsir Pimpinan Ar-Rahman kepada Pengertian Al-Quran. Kuala Lumpur: Jabatan Perdana Menteri.

Jelani, H. (2009). Bustan al-Salatin (The Garden of Kings): A Malay Mirror for Rulers. Pulau Pinang: Penerbit Universiti Sains Malaysia.

Jelani, H. (Ed.). 2008. Bustan al-Salatin: Kisah Raja-raja yang Adil (Bab Ketiga). Kuala Lumpur: Dewan Bahasa dan Pustaka.

Jones, R. (Ed.). (1985). Hikayat Sultan Ibrahim ibn Adham: An Edition of an Anonymous Malay Text with Translation and Notes. New York: University Press of America.

Jones, R. (Ed.). (1987). Hikayat Raja Pasai. Petaling Jaya: Penerbit Fajar Bakti.

Khalid, M. H. (Ed.). (1992). Taj al-Salatin. Kuala Lumpur: Dewan Bahasa dan Pustaka.

Lewis et al. (Eds.). (1983). The Encyclopedia of Islam (New edition). Leiden: E. J. Brill.

Mohd Yusof, M. N. (Ed.). (1989). Antologi Enam Hikayat. Petaling Jaya: Penerbit Fajar Bakti.

Muhammad, H. S. (1989). Puitika Sastera Melayu: Suatu Pertimbangan. Bangi: Penerbit Universiti Kebangsaan Malaysia.

Nasr, S. H. (1993). Spiritualitas dan Seni Islam. Translated by Sutejo. Bandung: Mizan.

Noridah, K. (2008). Dari Mestika ke Sang Pencinta: Nada-nada Sufi M. Nasir. MA Tesis. Universiti Kebangsaan Malaysia.

Shafie, A. B. (1996). Sastera Islam dalam Peradaban Ummah. Simposium Serantau Sastera Islam, Brunei: Dewan Bahasa dan Pustaka Brunei.

Shaiful Bahri, M. R. (2007). Mendepani Globalisasi: Suatu Sumbangan Kesusasteraan Melayu. In Armida et al. (Eds.), Indonesia dan Malaysia dalam Era Globalisasi dan Desentralisasi: Mewujudkan Kemakmuran Bersama. Bandung: Universitas Padjadjaran dan Universiti Kebangsaan Malaysia.

Siti Hawa, H. S. (2002). Kesusasteraan Melayu Abad Kesembilan Belas. Kuala Lumpur: Dewan Bahasa dan Pustaka. 
Ungku Maimunah, M. T. (2007). Kritikan Sastera Melayu: Antara Cerita dengan Ilmu. Bangi: Penerbit Universiti Kebangsaan Malaysia.

Ungku Maimunah, M. T. (Ed.). (2010). Kedudukan Ilmu dalam Kesusasteraan: Teori \& Praktis. Bangi, Selangor: Institut Alam dan Tamadun Melayu, UKM.

Wan Mohd Nor, W. D. (2005). Falsafah dan Amalan Pendidikan Islam Syed M. Naquib Al-Attas: Satu Huraian Konsep Asli Islamisasi. Kuala Lumpur: Penerbit Universiti Malaya. 